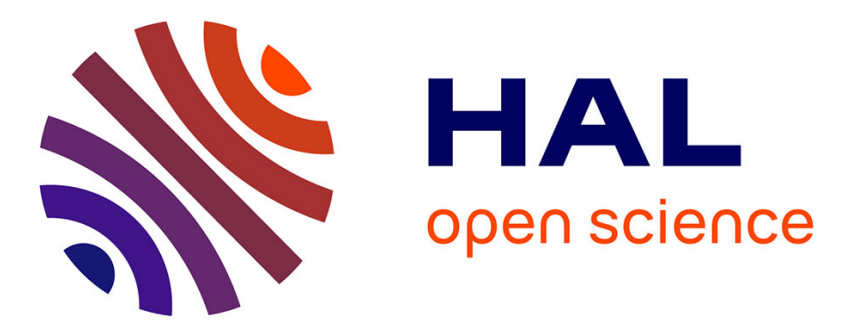

\title{
Inversion of Surface Soil Moisture from Radar Altimetry Backscattering in Semi-Arid Environments
}

\author{
Fabien Blarel, Frédéric Frappart, Éric Mougin, Catherine Ottlé, Manuela \\ Grippa, Guillaume Ramillien, Nina Raoult
}

\section{- To cite this version:}

Fabien Blarel, Frédéric Frappart, Éric Mougin, Catherine Ottlé, Manuela Grippa, et al.. Inversion of Surface Soil Moisture from Radar Altimetry Backscattering in Semi-Arid Environments. IGARSS 2018 - 2018 IEEE International Geoscience and Remote Sensing Symposium, Jul 2018, Valencia, Spain. IEEE, pp.9110-9113, 2018, 10.1109/IGARSS.2018.8518637 . hal-02389678

\section{HAL Id: hal-02389678 \\ https://hal.science/hal-02389678}

Submitted on 5 Nov 2021

HAL is a multi-disciplinary open access archive for the deposit and dissemination of scientific research documents, whether they are published or not. The documents may come from teaching and research institutions in France or abroad, or from public or private research centers.
L'archive ouverte pluridisciplinaire HAL, est destinée au dépôt et à la diffusion de documents scientifiques de niveau recherche, publiés ou non, émanant des établissements d'enseignement et de recherche français ou étrangers, des laboratoires publics ou privés.

\section{(ㅇ)(1) $\$$}

Distributed under a Creative Commons Attribution - NonCommerciall 4.0 International 


\title{
INVERSION OF SURFACE SOIL MOISTURE FROM RADAR ALTIMETRY BACKSCATTERING IN SEMI-ARID ENVIRONMENTS
}

\author{
Fabien Blarel ${ }^{1}$, Frédéric Frappart ${ }^{1,2}$, Eric Mougin ${ }^{2}$, Catherine Ottlé ${ }^{3}$, Manuela Grippa ${ }^{2}$, Guillaume \\ Ramillien $^{2}$, Nina Raoult ${ }^{3}$ \\ ${ }^{1}$ LEGOS-OMP, Toulouse, France \\ ${ }^{2}$ GET-OMP, Toulouse, France \\ ${ }^{3}$ LSCE, Gif-sur-Yvette, France
}

\begin{abstract}
Surface Soil Moisture (SSM) is a key parameter of water and energy balances in semi-arid areas. SSM is linearly related to the radar backscattering coefficients $\left(\sigma_{0}\right)$ over sand. Linear relationships are commonly used for inverting SSM in semi-arid areas from SAR and scatterometer data. Recent studies demonstrated that SSM can also be inversed from radar altimetry backscattering. An inversion method combining radar altimetry $\sigma_{0}$ and land surface model (LSM) outputs is proposed here.
\end{abstract}

Index Terms - Soil moisture, backscattering, radar altimetry

\section{INTRODUCTION}

Data from radar sensors on-board satellites, mostly SAR and scatterometers, are commonly used to monitor changes in land cover, vegetation density, SSM or flood extent (e.g., [1]-[4] over West and Central Africa). Recently, $\sigma_{0}$ from radar altimetry demonstrated a strong potential for the monitoring of land surface properties.

Radar altimetry backscattering coefficients acquired over West Africa (between $0^{\circ}$ and $25^{\circ} \mathrm{N}$ and $5^{\circ} \mathrm{W}-25^{\circ} \mathrm{E}$ ) at $\mathrm{S}, \mathrm{C}, \mathrm{Ku}$ and $\mathrm{Ka}$ bands using nadir-looking altimeters were analyzed over the major bioclimatic zones, soil and vegetation types encountered in this region was performed [5], [6]. The analysis of the backscattering coefficients acquired by Topex/Poseidon at Ku-band showed their decrease as vegetation in Sahel increases [7]. SSM in a semi-arid area was first retrieved using ENVISAT RA-2 backscattering coefficients over Sahelian savannahs in the Gourma region of Mali [8]. High correlations between $\sigma_{0}$ acquired at Ka-band by SARAL were also observed in West Africa [6]. The impact of soil moisture on radar altimetry waveforms at $\mathrm{Ku}$ and $\mathrm{Ka}$ bands was estimated through an electro-magnetic modeling study [9]. An inversion method of SSM using $\sigma_{0}$ from radar altimetry was implemented and tested over several semi-arid sites in Australia [10].
In this study, an inversion approach of SSM from radar altimetry backscattering coefficients is proposed using SSM from ORCHIDEE LSM. Comparisons against in situ measurements from several sites in West Africa (Mali and Senegal are performed).

\section{DATASETS}

\subsection{Altimetry data}

The radar altimetry data used in this study were acquired by ERS-2, ENVISAT, Jason-1 and 2 and SARAL. Altimetry data used in this study consist of high frequency measurements, sampled at 18 to $40 \mathrm{~Hz}$ depending on the mission, of the acquisition time and geographical location (longitude and latitude) as well as the backscattering coefficient at Ku-band for all the missions except SARAL and at Ka-band for SARAL. Backscattering coefficients are derived from the Offset Center of Gravity (OCOG) or Ice-1 retracking algorithm following earlier studies [5], [6], [8], [10] present in the Geophysical Data Records from the space agencies for all the missions except ERS-2 and from the reatrcking performed by Centre de Topographie des Océans et de l'Hydrosphère (CTOH) for ERS-2 [11]. They were made available by $\mathrm{CTOH}$ : http://ctoh.legos.obs-mip.fr.

\subsection{ORCHIDEE model outputs}

The Organizing Carbon and Hydrology In Dynamic Ecosystems (ORCHIDEE) is a LSM that describes soil temperature and vertical water transport dynamics and that also includes a a river routing scheme including floodplains coupled to simulated grid-cell runoff as well as a carbon cycle model [12]. In this study, soil moisture (SM) outputs were used in the inversion method presented in 3. Methods. These outputs are available from 2000 to 2010 at a spatial resolution of $0.5^{\circ}$ and a temporal resolution of one day. 


\subsection{Global surface water data}

The Global Surface Water dataset information on surface water extent over all land surfaces at a spatial resolution of $30 \mathrm{~m}$ based on Landsat images acquired since 1985 [13]. It is made available by the Joint Research Center (JRC https://global-surface-water.appspot.com/download).

\subsection{Soil map}

The Harmonized World Soil Database v 1.2 provides the composition in terms of soil units and the characterization of selected soil parameters (organic Carbon, $\mathrm{pH}$, water storage capacity, soil depth, cation exchange capacity of the soil and the clay fraction, total exchangeable nutrients, lime and gypsum contents, sodium exchange percentage, salinity, textural class and granulometry) at a spatial resolution of 30 ' [14]. It result of a collaboration between the FAO with IIASA, ISRIC-World Soil Information, Institute of Soil Science, Chinese Academy of Sciences (ISSCAS), and the Joint Research Centre of the European Commission (JRC).

\subsection{In situ soil moisture data}

In situ soil moisture data, acquired in the framework of the African Monsoon Multi-scale Analysis (AMMA - CATCH - http://www.amma-catch.org)) in Mali [15], were used for the validation of the altimetry-based SSM product.

\section{STUDY AREA AND METHODS}

Over semi-arid sandy areas, SSM is linearly related to the radar backscattering coefficient [2]:

$$
\operatorname{SSM}(\lambda, \varphi, \mathrm{t})=\mathrm{a}\left(\sigma_{0}(\lambda, \varphi, \mathrm{t})-\sigma_{0}{ }^{\text {dry }}(\lambda, \varphi)\right)+\mathrm{b}
$$

where $\sigma_{0}{ }^{\text {dry }}$ is the backscattering coefficient for dry soil surface conditions, $\lambda, \varphi, \mathrm{t}$ are respectively the longitude, latitude and time of measurement, $\mathrm{a}$ and $\mathrm{b}$ are two constant terms.

\subsection{Study area}

The study area where the approach is tested is the Gourma region in Mali. The Gourma region $\left(14.5-17.5^{\circ} \mathrm{N}\right.$ and $1-$ $\left.2^{\circ} \mathrm{W}\right)$, is a vast peneplain at between 250 and $330 \mathrm{~m}$ altitude [15]. In this region, the mean annual rainfall varies between 150 and $400 \mathrm{~mm}$ from north to south with interannual variations ranging between 15 and $30 \%$ of the annual rainfall. Rainfall occurs during the northern hemisphere summer, starting between May and July until September or October with a maximum in August [16].

\subsection{Selection of the valid altimetry data}

SSM and radar altimetry are linearly related over sandy areas. Altimetry data are considered valid when the soil type in the altimeter footprint (in a disk of $5 \mathrm{~km}$ of radius) is composed of more than $90 \%$ of sand. The presence of open water in the altimetry footprint strongly dominates the surface response [9]. As already observed in [8], the altimetry backscattering coefficients cannot be used for SSM retrieving when open waters are present in the altimetry footprint. Backscattering coefficients are filtered out when open water from [13] are found in the altimeter footprint (in a disk of $5 \mathrm{~km}$ of radius).

\subsection{Inversion of the valid altimetry data}

The inversion approach to retrieve SSM from $\sigma_{0}$ is based on generalized least squares criteria [17]. The solution is a linear combination of the radar altimetry backscattering coefficients, of the a priori information from ORCHIDEE SSM estimates and optimal coefficients fitting.

(2)

$$
\mathrm{SSM}=\mathrm{SSM}_{0}+\mathrm{CG}\left(\mathrm{C}_{\mathrm{D}}+\mathrm{C}_{\mathrm{M}}+\mathrm{GCG}^{\mathrm{T}}\right)\left(\sigma_{0}-\mathrm{GSSM}_{0}\right)
$$

where $\mathrm{SSM}_{0}$ is the initial solution from ORCHIDEE, C is the covariance obtained minimizing the prediction error, $\mathrm{C}_{\mathrm{D}}$ and $\mathrm{C}_{\mathrm{M}}$ are the are the a priori covariances from the altimeter observations and from the model and $G$ is the kernel linking parameters to data.

The a posteriori covariance matrix $\mathrm{C}^{\mathrm{P}}$ obtained after solving the linear system is defined as:

$$
\mathrm{C}^{\mathrm{P}}=\mathrm{C}-\mathrm{CG}^{\mathrm{T}}\left(\mathrm{GCG}^{\mathrm{T}}+\mathrm{C}_{\mathrm{D}}+\mathrm{C}_{\mathrm{M}}\right)^{-1} \mathrm{GC}
$$

The a posteriori uncertainties associated to the fitted SSM are given by the root-mean square of the diagonal elements of $\mathrm{C}^{\mathrm{P}}$ :

$$
\sigma^{\mathrm{P}}=\left(\operatorname{diag}\left(C^{\mathrm{P}}\right)\right)^{-1 / 2}
$$

The inversion will be performed using all the valid altimetry data present in a model cell at time t. The spatial resolution of the altimetry data is a couple of hundred meters along the track whereas the model cell is $0.5^{\circ}$. Valid altimetry data corresponds to data acquired over sand surfaces with no inland water present in the altimeter footprint based on the open water mask defined using the Global Water Data product.

\section{RESULTS}

In the Gourma region $\left(14.5-17.5^{\circ} \mathrm{N}\right)$, once the different selection criteria were applied (sandy soils and no open water in the altimeter footprint), the following altimetry data along ERS-2/ENVISAT/SARAL ground-track 0302 were considered (Fig. 1). 


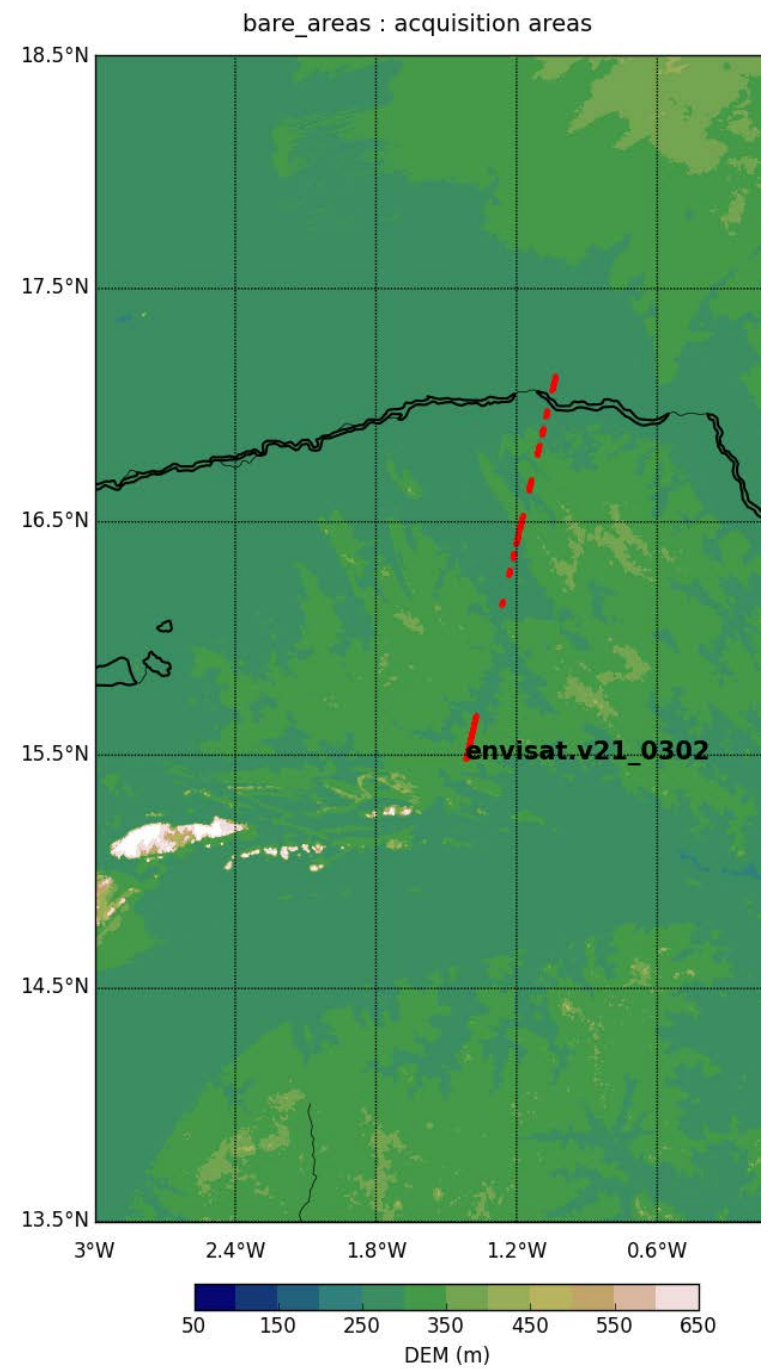

Fig. 1. Locations of the selected altimetry data along ERS2/ENVISAT/SARAL ground-track 0302 in the Gourma region of Mali.

Backscattering coefficients exhibit annual variations between 10 and $32 \mathrm{~dB}$ whereas SSM values range from 5 to $25 \%$. Maxima are observed during the rainy season, from June to September. Using these measurements, a linear regression was applied between ENVISAT altimetry backscattering coefficients (Ice-1) and soil moisture outputs from ORCHIDEE LSM (Layer-2c) over the period 20022009. The results are presented in Fig. 2. They show an overall good agreement with a $\mathrm{R}^{2}$ of 0.71 . Due to the coarse spatial resolution of the LSM grid step, plateaus are cearly visible at $5 \%$ of SSM for backscattering values between 10 and $15 \mathrm{~dB}$, at $8 \%$ for backscattering values between 15 and $25 \mathrm{~dB}$, and at $9 \%$ for backscattering values between 15 and $20 \mathrm{~dB}$.

\section{$\stackrel{\dddot{u}}{\Sigma} \prod_{0}$}

Fig. 2. Scatterplot between ENVISAT-RA-2 backscattering coefficients (Ice-1) and SSM from ORCHIDEE.

\section{CONCLUSION}

A good correlation was observed between radar altimetry coefficients and SSM from ORCHIDEE LSM over sandy areas without open water (temporary and permanent ponds) in the Gourma region of Mali $\left(\mathrm{R}^{2}=0.71\right)$ in spite of the difference of spatial resolution between the two datasets.

A method for inverting SSM from radar altimetry backscattering coefficients was developped. This method will be applied to backscattering coefficients from ERS-2 (1995-2003) and ENVISAT (2003-2010) ground-track 302 in the Sahelien Gourma region of Mali and from Jason-2 (2008-2016) ground-tracks 46 and 161 and SARAL (20132016) ground-tracks 1 and 846 in the Sahelian Ferlo region of Senegal.

\section{REFERENCES}

[1] P. L. Frison, E. Mougin, and P. Hiernaux, "Observations and Interpretation of Seasonal ERS-1 Wind Scatterometer Data over Northern Sahel (Mali)," Remote Sens. Environ., vol. 63, no. 3, pp. 233-242, Mar. 1998.

[2] W. Wagner and K. Scipal, "Large-scale soil moisture mapping in western Africa using the ERS scatterometer," IEEE Trans. Geosci. Remote Sens., vol. 38, no. 4, pp. 1777-1782, Jul. 2000.

[3] F. Baup et al., "Mapping surface soil moisture over the Gourma mesoscale site (Mali) by using ENVISAT ASAR data," Hydrol. Earth Syst. Sci., vol. 15, no. 2, 2011.

[4] J. Betbeder, V. Gond, F. Frappart, N. N. Baghdadi, G. Briant, and E. Bartholome, "Mapping of central 
africa forested wetlands using remote sensing," IEEE J. Sel. Top. Appl. Earth Obs. Remote Sens., vol. 7, no. 2, 2014.

[5] C. Fatras et al., "Spaceborne altimetry and scatterometry backscattering signatures at $\mathrm{C}$ - and Ku-bands over West Africa," Remote Sens. Environ., vol. 159, 2015.

[6] F. Frappart et al., "Radar altimetry backscattering signatures at $\mathrm{Ka}, \mathrm{Ku}, \mathrm{C}$, and $\mathrm{S}$ bands over West Africa," Phys. Chem. Earth, vol. 83-84, 2015.

[7] C. Prigent, F. Aires, C. Jimenez, F. Papa, and J. Roger, "Multiangle Backscattering Observations of Continental Surfaces in $\mathrm{Ku}-\mathrm{Band}(13 \mathrm{GHz})$ From Satellites: Understanding the Signals, Particularly in Arid Regions," IEEE Trans. Geosci. Remote Sens., vol. 53, no. 3, pp. 1364-1373, Mar. 2015.

[8] C. Fatras, F. Frappart, E. Mougin, M. Grippa, and P. Hiernaux, "Estimating surface soil moisture over Sahel using ENVISAT radar altimetry," Remote Sens. Environ., vol. 123, 2012.

[9] C. Fatras, P. Borderies, F. Frappart, E. Mougin, D. Blumstein, and F. Niño, "Impact of Surface Soil Moisture Variations on Radar Altimetry Echoes at $\mathrm{Ku}$ and $\mathrm{Ka}$ Bands in Semi-Arid Areas," Remote Sens., vol. 10, no. 4, p. 582, Apr. 2018.

[10] B. Uebbing, E. Forootan, A. Braakmann-Folgmann, and J. Kusche, "Inverting surface soil moisture information from satellite altimetry over arid and semi-arid regions," Remote Sensing of Environment, vol. 196. pp. 205-223, Jul-2017.

[11] F. Frappart et al., "An ERS-2 altimetry reprocessing compatible with ENVISAT for long-term land and ice sheets studies," Remote Sens. Environ., vol. 184, 2016.

[12] M. Guimberteau et al., "ORCHIDEE-MICT (revision 4126), a land surface model for the highlatitudes: model description and validation," Geosci. Model Dev. Discuss., pp. 1-65, Jun. 2017.

[13] J.-F. Pekel, A. Cottam, N. Gorelick, and A. S. Belward, "High-resolution mapping of global surface water and its long-term changes," Nature, vol. 540, no. 7633, pp. 418-422, Dec. 2016.

[14] W. R. Wieder, J. Boehnert, G. B. Bonan, and Langseth M., "Regridded Harmonized World Soil Database v1.2, https://doi.org/10.3334/ORNLDAAC/1247,", 2014. [Online]. Available: https://daac.ornl.gov/cgibin/dsviewer.pl?ds_id=1247. [Accessed: 03-May2018].

[15] E. Mougin et al., "The AMMA-CATCH Gourma observatory site in Mali: Relating climatic variations to changes in vegetation, surface hydrology, fluxes and natural resources," J. Hydrol., vol. 375, no. 1-2, 2009.

[16] F. Frappart et al., "Rainfall regime across the Sahel band in the Gourma region, Mali," J. Hydrol., vol. 375, no. 1-2, pp. 128-142, 2009.

[17] A. Tarantola, Inverse problem theory and methods for model parameter estimation. Society for Industrial and Applied Mathematics, 2005. 